\title{
PEMANFAATAN ANGGUR LAUT (Caulerpa recemosa) DALAM PEMBUATAN SUP KRIM INSTAN
}

\section{UTILIZATION OF Caulerpa recemosa IN THE PRODUCTION OF INSTANT CREAM SOUP}

\author{
Dhanang Puspita $\left.{ }^{1,2}\right)^{*}$, Windu Merdekawati ${ }^{3)}$, dan Nella Suryani Rahangmetan ${ }^{1)}$ \\ ${ }^{1)}$ Program Studi Teknologi Pangan, Universitas Kristen Satya Wacana, \\ Jl. Kartini No.11A, Salatiga 50711, Indonesia \\ Email: dhanang.puspita@uksw.edu \\ ${ }^{2)}$ Carotenoid and Antioxidant Research Center, Universitas Kristen Satya Wacana, Salatiga, Indonesia \\ ${ }^{3)}$ Program Pasca Sarjana Biologi, Universitars Gadjah Mada, Yogyakarta \\ Makalah: Diterima 28 Agustus 2018; Diperbaiki 2 Januari 2019; Disetujui 15 Januari 2019
}

\begin{abstract}
Caulerpa recemosa is one type of seaweed commonly used as a snack in raw form. High water content causes Caulerpa recemosa susceptible to damage. One effort to utilize Caulerpa recemosa is to process it to instant cream soup. The purpose of this study was to process Caulerpa recemosa into instant cream soup and done proximate analysis so as sensory evaluation. The methods done in this research were instant cream soup processing using vacuum drying oven then proximate analysis and sensory evaluation. The results of this research was that instant cream soup produced in this research equipped with green characteristics and seaweed scent. Based on the results of the proximate analysis, the instant cream soup contained water content $(5.78 \%)$, ash (17.82\%), protein (5.74\%), fat (17.50\%), and carbohydrate (60.87\%). Sensory evaluation, visually, and taste showed a significant difference between instant cream soup and control, while texture, aroma and overall acceptance were not significantly different. Instant cream soup Caulerpa recemosa has distinctive characteristics for the colour and aroma that can be as added value, besides it also had good nutritional value and can be accepted by consumers. It could be concluded that Caulerpa recemosa could be processed into instant cream soup and has nutritional value and could be accepted by panelists.
\end{abstract}

Keywords: Caulerpa recemosa, cream soup instant, vacuum drying oven, utilization

\section{ABSTRAK}

Caulerpa recemosa adalah salah satu jenis rumput laut yang biasa dijadikan kudapan dalam bentuk segar. Kandungan air yang tinggi menyebabkan Caulerpa recemosa rentan terhadap kerusakan. Salah satu upaya pemanfaatan Caulerpa recemosa adalah mengolah menjadi sup krim instan. Tujuan dari penelitian ini adalah mengolah Caulerpa recemosa menjadi sup krim instan dan menguji kandungan proksimat dan organoleptik. Metode penelitian meliputi produksi sup krim instan dengan menggunakan vacuum drying oven kemudian diuji proksimat dan uji organoleptik. Dari hasil penelitian diperoleh produk sup krim instan dengan karateristik berwarna hijau dan beraroma rumput laut. Berdasarkan hasil analisis proksimat sop krim instan mempunyai kadar air (5,78\%), abu (17,82\%), protein (5,74\%), lemak (17,50\%), dan karbohidrat (60,87\%). Hasil uji organoleptik, secara visual dan rasa menunjukkan beda nyata antara sup krim instan dengan kontrol, sedangkan tekstur, aroma dan penerimaan keseluruhan tidak berbeda nyata. Sup krim instan Caulerpa recemosa memiliki karakteristik yang khas yakni warna dan aroma yang dapat menjadi nilai tambahnya, selain itu juga memiliki nilai gizi yang baik dan dapat diterima oleh konsumen. Dapat disimpulkan, Caulerpa recemosa dapat diolah menjadi sup krim instan dan memiliki nilai gizi serta dapat diterima oleh panelis.

Kata kunci: Caulerpa recemosa, sup krim instan, vacuum drying oven, pemanfaatan

\section{PENDAHULUAN}

Indonesia merupakan negara kepulauan yang memiliki wilayah laut yang sangat luas dibandingkan daratan. Tiga perempat wilayah Indonesia adalah laut $\left(5,9\right.$ juta $\left.\mathrm{km}^{2}\right)$, dengan panjang garis pantai $95,161 \mathrm{~km}$, terpanjang kedua setelah Kanada (Lasabuda, 2013). Perairan Indonesia yang luas dan subur tentunya memiliki beraneka ragam sumber daya alam, salah satunya pada sektor kelautan. Indonesia merupakan negara penghasil rumput laut yang sangat tinggi sehingga dikenal di mata dunia sebagai bank rumput laut (Santosa et al., 2016). Namun pemanfataan rumput laut di Indonesia masih terbatas sebagai bahan makanan penduduk pesisir. Rumput laut Indonesia sekitar 80\% diekspor dalam bentuk kering dengan harga relatif rendah, dan hanya $20 \%$ yang diolah di dalam negeri. Oleh karena itu perlu adanya pengembangan produk melalui proses pengolahan rumput laut yang mampu menghasilkan nilai tambah (Hikmah, 2013).

Rumput laut berpotensi sebagai sumber gizi karena umumnya mengandung karbohidrat, protein, dan sedikit lemak, serta vitamin dan mineral 
(Hambali et al., 2004). Rumput laut mengandung air yang tinggi yaitu sekitar $80-90 \%$, protein $17-$ $27 \%$, lemak $0,08-1,9 \%$, karbohidrat $39-50 \%$, serat $1,3-12,4 \%$ dan abu $8,15-16,9 \%$ (Hartomo, 1993). Salah satu jenis rumput laut yang tumbuh melimpah di perairan Indonesia, namun masih minim dalam pemanfaatannya adalah Caulerpa recemosa.

Caulerpa recemosa merupakan salah satu jenis rumput laut dari kelas Chlorophyceae. Spesies ini dikenal dengan sebutan anggur laut karena bentuknya menyerupai buah anggur. Di Indonesia Caulerpa recemosa dikenal dengan sebutan latoh (Jawa), bulung boni (Bali), lawi-lawi (Sulawesi), lat (Maluku), sedangkan di Jepang disebut Umi Budo (Yudasmara, 2014). Umumnya rumput laut ini hanya dimanfaatkan sebagai makanan dalam bentuk mentah (salad).

Potensi pengembangan rumput laut hijau ini cukup besar karena mengandung zat gizi yang diperlukan tubuh, dan telah dikenal oleh sebagian masyarakat. Beberapa jenis rumput laut merupakan sumber potensial pangan fungsional yang dapat dimanfaatkan untuk kesehatan karena mengandung senyawa kimia yang mempunyai aktivitas biologis (zat bioaktif). Senyawa aktif biologis itu merupakan metabolit sekunder yang meliputi alkaloid, flavonoid, terpenoid, tannin, dan saponin (Lantah et al., 2017). Umumnya rumput laut memiliki kadar air yang cukup tinggi, sama seperti Caulerpa recemosa sehingga rentan akan kerusakan jika tidak ditangani secara cepat. Perlu upaya yang inovatif untuk memanfaatkan potensi lokal tersebut. Salah satu upaya yang dapat dilakukan adalah dengan mengolah Caulerpa recemosa dalam pembuatan sup krim instan menggunakan vacuum drying oven (VDO). VDO merupakan mesin pengering untuk mengeluarkan air suatu bahan dengan menggunakan tekanan. Suhu yang digunakan lebih rendah, sehingga mampu mempertahankan kualitas suatu bahan. Suhu pemanasan untuk menguapkan air bisa dicapai pada suhu $60-70^{\circ} \mathrm{C}$ (Asgar et al., 2013).

Sup krim instan merupakan produk olahan tepung nabati atau hewani, dengan atau tanpa bahan tambahan lain, yang dapat dikonsumsi setelah dimasak atau hanya dengan diseduh air mendidih menjadi larutan kental (BSN, 1999). Seiring perkembangan jaman, masyarakat cenderung lebih menyukai produk pangan instan (Fellow dan Ellis, 1992). Sup krim dapat disajikan untuk sarapan, jamuan lengkap dan makan ringan atau selingan. Sup juga sebagai hidangan pembuka sebelum hidangan utama (main course) yang disajikan dengan tujuan membangkitkan nafsu makan atau selera makan karena itu porsinya kecil dengan rasa gurih (Irwan, 2017).

Makanan instan yang beredar di pasaran belum terlalu banyak berasal dari biota laut, sehingga produk instan dari Caulerpa recemosa diharapkan mampu bersaing di masyarakat. Tujuan dari penelitian ini adalah mengolah Caulerpa recemosa menjadi sup krim isntan dan menguji kandungan proksimat dan organoleptik.

\section{BAHAN DAN METODE}

\section{Bahan}

Bahan yang digunakan berupa rumput laut hijau (Caulerpa recemosa) yang diperoleh dari perairan utara Jepara-Jawa Tengah, tepung terigu, tepung maizena, bubuk susu full krim, bawang bombay, bawang putih, merica bubuk, seledri, garam. Bahan-bahan yang digunakan dalam analisa kimia adalah asam sulfat $\left(\mathrm{H}_{2} \mathrm{SO}_{4}\right)$ (Merck), Natrium hidroksida pekat $(\mathrm{NaOH})$ (Merck), Asam klorida (HCl) 0,02 M (Merck), aquades. Peralatan yang akan digunakan adalah vacuum dryer, ayakan, penepung, alat masak (kompor gas, blender, loyang, timbangan, talenan, piring aluminium, sendok, spatula, ulekan, gelas), desikator, erlenmeyer, cawan porselin, tanur, aluminium foil, oven, buret, labu Kjeldahl dan alat ekstraksi Soxhlet.

\section{Metode}

\section{Rancangan Penelitian}

Penelitian ini menggunakan jenis penelitian eksperimental laboratoris. Analisa yang dilakukan yaitu analisa proksimat dan analisa sensori. Hasil data yang diperoleh dianalisis secara deskriptif dan dihitung menggunakan software Microsoft Office Excel dan statistic SPSS versi 16.0 dengan menggunakan uji Mann-Whitney. Mann-Whitney merupakan uji turunan dari T-test untuk melihat perbedaan yang nyata antara dua sampel yang berbeda yaitu sampel sup krim instan Caulerpa recemosa dan sup krim ayam instan (komersial) sebagai kontrol. Uji ini digunakan untuk melihat sampel sup krim instan Caulerpa recemosa apakah memiliki perbedaan secara nyata atau tidak berkaitan dengan penerimaan secara organoleptik oleh panelis. Uji proksimat mengacu pada AOAC (2005) dengan 3 kali pengulangan.

\section{Pembuatan Krim Sup Instan}

Pengolahan diawali dengan penumisan bumbu (bawang 12,8 g, garam $8 \mathrm{~g}$, merica 2,6 g, penyedap 1,3 g), dengan margarin 1,6 g. Sebanyak 800 g Caulerpa recemosa yang sudah dihancurkan dengan blender kemudian ditambahkan tepung terigu $80 \mathrm{~g}$ dan maizena $80 \mathrm{~g}$ yang sudah dicampur dengan air sebanyak $1 \mathrm{~L}$. Adonan selanjutnya diaduk hingga tercampur rata dan dicampur dengan bumbu yang sudah ditumis. Adonan dipanaskan pada suhu $100^{\circ} \mathrm{C}$ selama \pm 25 menit. Proses selanjutnya adonan dikeringkan ke dalam VDO selama \pm 120 menit dengan suhu $60^{\circ} \mathrm{C}$ dan tekanan $-60 \pm 5 \mathrm{cmHg}$. Adonan yang sudah dikeringkan selanjutnya dihaluskan dengan alat penepung, diayak dengan saringan dan disimpan dalam plastik. Formulasi sup krim instan dapat dilihat pada Tabel 1. 


\section{Uji Orgonoleptik}

Pengujian sensori dilakukan terhadap atribut tekstur, warna, rasa, aroma dan tingkat penerimaan produk secara keseluruhan dengan menggunakan uji hedonik. Panelis yang dibutuhkan sebanyak 35 orang yang tidak terlatih. Panelis diminta untuk memberikan penilaian terhadap sampel sup Caulerpa recemosa dan sampel kontrol (sup krim komersial). Skala yang digunakan pada uji hedonik ialah skala 1 sampai 5 yang terdiri dari: (1) sangat tidak suka; (2) tidak suka; (3) cukup suka; (4) suka; (5) sangat suka.

Tabel 1. Formulasi sup krim Instan

\begin{tabular}{lcc}
\hline \multicolumn{1}{c}{ Bahan } & $\begin{array}{c}\text { Jumlah } \\
(\boldsymbol{\%})\end{array}$ & $\begin{array}{c}\text { Jumlah } \\
(\mathbf{g})\end{array}$ \\
\hline Caulerpa sp. & 80 & 800 \\
Tepung Terigu & 8 & 80 \\
Tepung Maizena & 8 & 80 \\
Bubuk Susu Full Krim & 1,36 & 13,6 \\
Garam & 0,8 & 8 \\
Merica & 0,26 & 2,6 \\
Bawang Putih & 1,28 & 12,8 \\
Penyedap & 0,13 & 1,3 \\
Margarin & 0,16 & 1,6 \\
\hline
\end{tabular}

\section{Uji Proksimat (AOAC, 2005)}

Analsis kadar air dilakukan dengan menimbang sebanyak $5 \mathrm{~g}$ sampel sup krim instan beserta dengan cawan petri yang sudah diketahui beratnya, kemudian dioven pada suhu $100-105^{\circ} \mathrm{C}$ selama $3-5$ jam. Setelah dioven kemudian didinginkan dalam desikator. Setelah dingin kemudian ditimbang dengan menggunakan timbangan analitik. Rumus penghitungan berat dinyatakan dalam rumus:

$$
\text { Kadar air }=\frac{\text { berat awal }- \text { berat akhir }}{\text { berat sampel }} \times 100 \%
$$

Analisis kadar abu dilakukan dengan menimbang $2 \mathrm{~g}$ sampel dalam cawan porselen yang sudah diketahui beratnya kemudian dikeringkan dalam muffle pada suhu $500-600^{\circ} \mathrm{C}$ selama $3-5$ jam. Setelah dikeringkan kemudian didinginkan dengan cara dipindahkan dalam desikator lalu ditimbang. Penghitungan kadar abu ditetapkan dalam rumus:

$$
\text { Kadar abu }=\frac{\text { berat } a b u}{\text { berat sampel }} \times 100 \%
$$

Analisis kadar protein dilakukan dengan tiga tahapan, yaitu destruksi, destilasi, dan titrasi.

1. Tahap destruksi; Sampel ditimbang sebanyak 0,5 g kemudian dimasukkan ke dalam labu Kjeldahl. Satu butir selenium dimasukkan ke dalam tabung tersebut dan ditambahkan $3 \mathrm{~mL} \mathrm{H}_{2} \mathrm{SO}_{4}$. Tabung yang berisi larutan tersebut dimasukkan ke dalam alat pemanas dengan suhu $410^{\circ} \mathrm{C}$ ditambah $10 \mathrm{~mL}$ air. Proses destruksi dilakukan sampai larutan menjadi jernih.

2. Tahap destilasi; Larutan hasil destruksi didinginkan, kemudian ditambahkan $50 \mathrm{~mL}$ akuades dan $20 \mathrm{~mL} \mathrm{NaOH} \mathrm{40 \%} \mathrm{lalu} \mathrm{didestilasi.}$ Hasil destilasi kemudian ditampung di dalam erlenmeyer $125 \mathrm{~mL}$ yang berisi $25 \mathrm{~mL}$ asam borat $\left(\mathrm{H}_{3} \mathrm{BO}_{3}\right) \quad 2 \%$ yang mengandung indikator bromcresol green $0,1 \%$ dan methyl red $0,1 \%$ dengan perbandingan $2: 1$ dan hasil destilat berwarna hijau kebiruan.

3. Tahap titrasi; Titrasi dilakukan dengan menggunakan $\mathrm{HCl}$ sampai warna larutan pada erlenmeyer berubah warna menjadi merah muda. Volume titrasi dibaca dan dicatat. Perhitungan kadar protein pada sup krim instan dapat dihitung dengan;

$$
\begin{aligned}
& \text { \% Nitrogen } \\
& =\frac{(m L H C l \text { sampel }-m L \mathrm{HCl} \text { blangko }) \times \mathrm{N} \mathrm{HCl} \times 14}{m g \text { sup krim instan }} \\
& \times 100 \%
\end{aligned}
$$

$$
\begin{aligned}
\text { kadar protein } & =\% \text { Nitrogen } \\
& \times \text { faktor konversi }(6,25)
\end{aligned}
$$

Analisis kadar lemak dilakukan dengan cara sampel sup krim instan sebanyak 2 g (W1) ditimbang dan dimasukkan ke dalam kertas saring lalu dimasukkan ke dalam selongsong lemak. Setelah dimasukan dalam selongsong lemak kemudian dimasukkan ke dalam labu lemak yang sudah ditimbang berat tetapnya (W2) dan disambungkan dengan tabung Soxhlet. Selongsong lemak dimasukkan ke dalam ruang ekstraktor tabung soxhlet dan disiram dengan pelarut lemak. Tabung ekstraksi kemudian dipasang pada alat destilasi soxhlet lalu dipanaskan pada suhu $40^{\circ} \mathrm{C}$ dengan pemanas listrik selama 6 jam. Pelarut lemak yang ada dalam labu lemak didestilasi hingga semua pelarut lemak menguap. Pada saat destilasi pelarut akan tertampung di ruang ekstraktor, kemudian pelarut dikeluarkan sehingga tidak kembali ke dalam labu lemak, selanjutnya labu lemak dikeringkan dalam oven pada suhu $105^{\circ} \mathrm{C}$. Setelah dikeringkan, lalu labu didinginkan dalam desikator sampai beratnya konstan (W3). Kadar lemak sup krim instan dihitung dengan rumus:

$$
\text { Kadar lemak }=\frac{W 3-W 2}{W 1} \times 100 \%
$$

Penghitungan kadar karbohidrat dilakukukan by difference, yakni dengan hasil pengurangan $100 \%$ dengan kadar air, kadar abu, kadan protein, dan kadar lemak. Kadar karbohidrat dapat dihitung dengan rumus:

\section{Kadar karbohidrat}

$$
\begin{aligned}
& =100 \%-(\% \text { abu }+\% \text { air } \\
& +\% \text { lemak }+\% \text { protein })
\end{aligned}
$$




\section{HASIL DAN PEMBAHASAN}

Caulerpa recemosa adalah salah satu jenis alga hijau (Gambar 1a) yang dapat dijadikan sebagai sebagai bahan baku dalam memproduksi sup krim instan (Gambar 1a dan 1b). Sup krim instan berbahan dasar Caulerpa recemosa memiliki warna hijau dan aroma khas rumput laut (Gambar 1c). Sup krim instan dari Caulerpa recemosa mempunyai kandungan nutrisi antara lain karbohidrat, protein, lemak, dan abu yang ditunjukkan pada Tabel 2 .

Dari hasil uji organoleptik dengan membandingkan sup krim instan Caulerpa recemosa (P1) dengan sup krim instan komersial (P2) sebagai kontrol yang ditunjukkan pada Tabel 3. Pada sup krim isntan Caulerpa recemosa (P1) secara visual panelis cenderung cukup suka, tekstur dan aroma cenderung suka, rasa panelis cenderung cukup suka sampai suka. Secara keseluruhan panelis cenderung menyukai.
Tabel 2. Hasil analisis proksimat krim sup instan Caulerpa recemosa

\begin{tabular}{lc}
\hline \multicolumn{1}{c}{ Komponen Gizi } & Jumlah $(\%)$ \\
\hline Kadar abu & $17,82 \pm 0,57$ \\
Kadar air & $5,78 \pm 0,25$ \\
Kadar protein & $5,74 \pm 0,63$ \\
Kadar lemak & $17,50 \pm 1,23$ \\
Kadar karbohidrat & $60,87 \pm 0,45$ \\
\hline
\end{tabular}

Tabel 4 menunjukkan hasil uji MannWhitney sup krim instan dengan kontrol. Dasar pengambilan keputusan yaitu $\mathrm{p}<0,05$ maka terdapat perbedaan nyata antara sup krim instan Caulerpa recemosa dengan kontrol sedangkan $\mathrm{p}>0,05$ maka tidak terdapat perbedaan nyata antara sup krim instan dengan kontrol. Secara visual dan rasa menunjukkan beda nyata antara sup krim instan Caulerpa recemosa dengan kontrol, dimana kontrol lebih baik. Parameter tekstur, aroma dan penerimaan keselurahan tidak berbeda nyata.

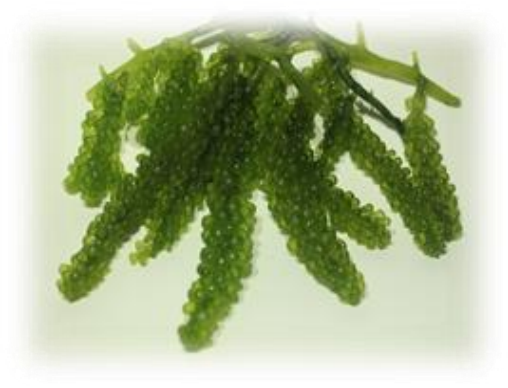

(a)

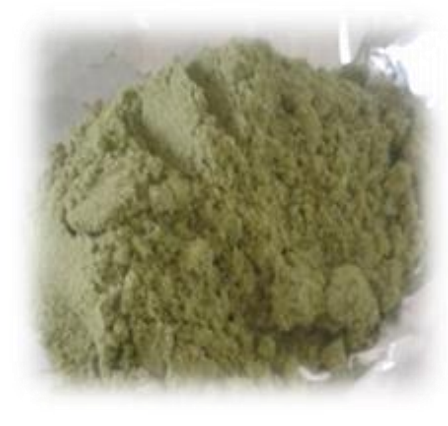

(b)

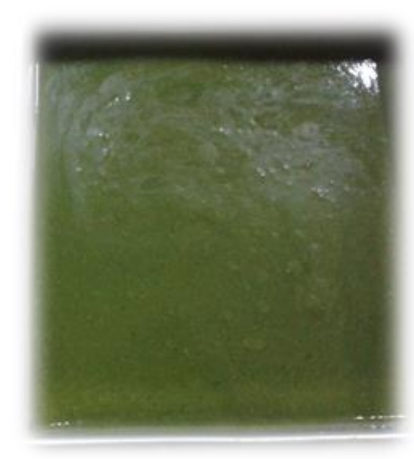

(c)

Gambar 1. (a) Caulerpa recemosa, (b) tepung sup krim, dan (c) produk sup krim instan

Tabel 3. Nilai rata-rata sensori

\begin{tabular}{llccccc}
\hline & \multicolumn{4}{c}{ Hasil Penilaian } & $\begin{array}{c}\text { Penerimaan } \\
\text { keseluruhan }\end{array}$ \\
\cline { 3 - 6 } & Visual & Tekstur & Rasa & Aroma & \\
\hline P1 & Rata-rata & 3,17 & 3,49 & 3,14 & 3,31 & 3,49 \\
& N & 3,83 & 3,74 & 3,4 & 3,80 & 3,89 \\
& & 35 & 35 & 35 & 35 & 35 \\
\hline
\end{tabular}

Keterangan :

$\mathrm{N}=$ jumlah data; $\mathrm{P} 1=$ Produk yang dihasilkan; $\mathrm{P} 2=$ Kontrol

$1=$ sangat tidak suka; $2=$ tidak suka; $3=$ cukup suka; $4=$ suka; $5=$ sangat suka

Tabel 4. Hasil uji Mann-Whitney

\begin{tabular}{lccccc}
\hline & \multicolumn{5}{c}{ Hasil Penilaian } \\
\cline { 2 - 5 } & Visual & Tekstur & Rasa & Aroma & Keseluruhan \\
\hline Mann-Whitney U & 390,0 & 496,0 & 418,0 & 456,5 & 475,0 \\
N & 35 & 35 & 35 & 35 & 35 \\
Asymp. Sig. (2-tailed) & $0,006^{*}$ & 0,133 & $0,018^{*}$ & 0,052 & 0,085 \\
\hline
\end{tabular}

Keterangan:

*Berbeda nyata antara sup krim Caulerpa recemosa. instan dengan kontrol $(\mathrm{p}<0,05)$. 


\section{Sup Krim Instan}

Caulerpa recemosa salah satu spesies rumput laut yang terdistribusi luas di perairan tropis. Acapkali kehadiran jenis rumput laut ini menjadi gulma bagi rumput budi daya, karena dapat mengganggu pertumbuhan rumput laut yang memiliki nilai ekonomi tinggi (Ornamo et al., 2014). Karena dianggap gulma, maka rumput laut ini tidak dibudidayakan dan pemanfaatannya sebatas sebagai kudapan dalam bentuk segar. Dari nilai gizi, Caulerpa recemosa segar memiliki kandungan karbohidrat 48,68 mg/g, lemak 8,68 mg/g, dan protein 21,73 mg (Farid et al., 2013). Berdasar kandungan nilai gizi bisa dijadikan produk olahan pangan dan salah satunya dalam bentuk sup krim instan.

Produk sup krim instan dari Caulerpa recemosa memiliki karakteristik yang khas yakni berwarna hijau dan aroma khas rumput yang tidak ada pada sup krim yang ada di pasaran. Dua karakteristik menjadi nilai tambah, namun subyektifitas dan perspektif konsumen menjadi kendala. Selama ini sup krim instan identik dengan warna putih dan aroma khas daging.

Dengan adanya inovasi pangan ini, maka Caulerpa recemosa bisa dijadikan sebagai bahan baku utama, dengan begitu nilai ekonomisnya akan bertambah. Selain terjadi peningkatan nilai ekonomi, juga ada diversifikasi produk berbasis rumput laut. Selama ini pemanfaatan rumput laut identik dengan pengolahan karagenan dan produk turunannya.

\section{Nilai Gizi}

Penentuan kadar abu ialah mengetahui banyaknya total mineral yang terkandung dalam suatu produk pangan. Tabel 2 menunjukkan kandungan abu sup krim instan sebesar $17,82 \%$. Kandungan mineral (abu) pada produk disebabkan oleh cukup tingginya kandungan mineral pada Caulerpa recemosa. Menurut Pattama dan Chirapart (2006), kandungan abu pada Caulerpa lentillifera sebesar $24,21 \%$.

Tabel 2 menunjukkan kandungan air sup krim instan sebesar 5,78\% dan memenuhi standar SNI. Standar tersebut menghendaki agar kandungan air suatu bahan pangan dikurangi sampai suatu batas agar mikroba tidak dapat tumbuh lagi di dalamnya (Winarno, 1980). Standar kadar air yang ditentukan yaitu $2-7 \%$. Umumnya Caulerpa sp mengandung jumlah air yang tinggi. Air yang terkandung dalam suatu produk pangan dapat memengaruhi penerimaan dan umur simpan produk pangan tersebut.

Kandungan protein pada sup krim instan Caulerpa recemosa sebesar $5,74 \%$ dan tidak memenuhi standar mutu SNI. Rendahnya kadar protein pada produk sup krim instan dikarenakan kandungan protein Caulerpa recemosa yang cukup rendah. Proses pemanasan dan pengeringan kemungkinan menyebakan kerusakan protein, sehingga besarannya menurun.

Berdasarkan hasil analisis proksimat pada Tabel 2, menunjukkan kandungan lemak sup krim instan sebesar $17,50 \%$ dan tidak memenuhi standar mutu. Standar mutu (SNI 1996) kandungan lemak sup krim instan maksimal $10 \%$. Umumnya rumput laut tidak kaya akan lemak. Tingginya kandungan lemak pada produk sup krim instan dipengaruhi adanya penambahan bahan yang kaya akan lemak seperti susu full krim dan margarin.

Perhitungan kadar karbohidrat dengan metode by difference. Berdasarkan hasil analisis proksimat pada Tabel 2, kandungan karbohidrat sup krim instan sebesar 60,87\%. Umumnya Caulerpa recemosa mengandung karborhidrat cukup tinggi. Berdasarkan penelitian Pattama dan Chirapart (2006), kandungan karbohidrat pada spesies Caulerpa lentillifera sebesar $59,27 \%$ dalam berat kering.

\section{Analisis Sensori}

Visual merupakan atribut penting dalam pemilihan suatu produk pangan, yang dianggap memiliki rasa yang enak dan berkualitas tinggi. Visual mencakup penglihatan terhadap bentuk dan warna merupakan daya tarik produk pangan. Umumnya sup krim instan berwarna putih, dikarenakan adanya pencampuran tepung. Warna sup krim instan ialah hijau muda, merupakan warna alami Caulerpa recemosa yang sebenarnya bisa menjadi penciri khas sup krim instan.

Sup krim instan Caulerpa recemosa memiliki warna hijau yang berasal dari pigmen klorofil dari rumput laut. Menurut Sarojini et al. (2015) Caulerpa recemosa memiliki kandungan klorofil a $(10,08-17,4 \mu \mathrm{g} / \mathrm{mL})$ dan klorofil b $(15,2$ - 31,2 $\mu \mathrm{g} / \mathrm{mL}$ ), sedangkan Sanchez et al. (2018) melaporkan kandungan klorofil a $(3,0151 \pm 0,4273$ $\mu \mathrm{g} / \mathrm{mL})$, klorofil b $(3,4289 \pm 1,1454 \mu \mathrm{g} / \mathrm{mL})$.

Warna hijau dari klorofil ini dapat dijadikan sebagai salah satu inovasi dalam pemanfaatan pewarna alami sup krim. Klorofil yang dikonsumsi dapat membantu dalam penyerapan zat gizi, membersihkan saluran pembuluh darah, menjaga $\mathrm{pH}$ darah (asam basa), mengurangi bau mulut, dan menjaga kesehatan sistem pencernaan. Manfaat lain dari klorofil adalah untuk meningkatkan imunitas tubuh, sumber energi, anti depresan pada susunan saraf pusat, mencegah konstipasi, perbaikan jaringan, dan membantu pembentukan hemoglobin (Merdekawati dan Susanto, 2009).

Warna hijau dalam sup krim instan Cauleroa recemosa menjadi indikator adanya kandungan klorofil. Pengolahan menggunakan VDO mampu mereduksi kerusakan klorofil akibat pemaparan panas, karena hanya menggunakan suhu $60-70^{\circ} \mathrm{C}$. Menurut Lípová et al. (2010), paparan panas pada klorofil sebaikya pada suhu tidak lebih dari $60^{\circ} \mathrm{C}$, karena jika melebihi akan merusak membran 
tilakoid dan mengarah pada pembentukan radikal bebas.

Aroma merupakan daya tarik yang sangat kuat bagi konsumen dalam pemilihan produk makanan, aroma mampu merangsang indera penciuman. Aroma sup krim instan Caulerpa recemosa khas rumput laut yaitu bau cukup amis. Bau amis yang ditimbulkan disebabkan adanya kandungan asam amino. Kemunculan aroma amis seiring berkurangnya kesegaran rumput laut karena menguapnya amonia, trimehlamin, dan asam lemak (Tarigan et al., 2016).

Aroma rumput laut yang khas yakni cenderung amis menjadi menjadi salah satu penciri dari sup krim instan ini. Aroma sebagai salah satu penentu tingkat kesukaan konsumen, namun dari hasil uji organoleptik tidak ada perbedaan yang signifikan. Sifat aroma yang mudah menguap pada paparan panas dapat diminimalisir dengan penggunaan VDO, sehingga aroma rumput laut masih dapat dipertahankan.

Tekstur berhubungan dengan kelembutan dan kekerasan suatu produk makanan yang melibatkan indera peraba, perasa dan penglihatan. Tekstur berhubungan dengan viskositas (kekentalan). Tidak ada perbedaan secara signifikan antara sup krim rumput laut dan kontrol, sehingga tidak terdapat perbedaan nyata antara sup krim instan dengan kontrol, yang artinya produk yang dihasilkan dapat bersaing dengan produk komersil.

Rasa merupakan faktor penting dalam pemilihan makanan mengunakan mulut. Konsumen akan menerima suatu produk makanan tergantung dari enak atau tidaknya produk tersebut. Rasa dalam sup krim instan didominasi oleh Caulerpa recemosa dengan khas gurih dan amis laut. Bahan tambahan pada pembuatan sup krim instan kurang memengaruhi cita rasa yang ditimbulkan.

Penerimaan secara keseluruhan sup krim instan Caulerpa recemosa yang dibandingkan dengan kontrol yang merupakan produk komersial tidak berbeda nyata. Dengan demikian, sup krim isntan Caulerpa recemosa bisa diterima oleh masyarakat, meskipun tidak sebaik sup krim komersial. Perlu adanya penelitian lebih lanjut dengan melihat adanya potensi klorofil dan aroma khas rumput laut sebagai penciri utamanya.

\section{Potensi Peluang Industri}

Indonesia sebagai negara maritim memiliki potensi budi daya rumput laut yang besar. Caulerpa recemosa yang bukan merupakan produk unggulan dari rumput laut, karena kandungan karagenan yang rendah dibanding rumput laut jenis lain. Caulerpa recemosa memiliki kandungan klorofil yang bisa dijadikan nilai tambahnya, sebab klorofil memiliki banyak manfaat dalam bidang kesehatan. Nilai ekonomi Caulerpa recemosa yang rendah bisa diangkat dengan memanfaatkanya menjadi produk sup krim instan dan memberikan perspektif baru pada masyarakat tentang sup krim instan berbasis rumput laut.

\section{KESIMPULAN DAN SARAN}

\section{Kesimpulan}

Caulerpa recemosa dapat diolah menjadi sup krim isntan dengan karakteristik berwarna hijau dan beraroma khas rumput laut. Kandungan nutrisi sup krim instan Caulerpa recemosa (\%); kadar abu $(17,82 \pm 0,57)$, kadar air $(5,78 \pm 0,25)$, kadar protein $(5,74 \pm 0,63)$, kadar lemak $(17,50 \pm 1,23)$, dan kadar karbohidrat $(60,87 \pm 0,45)$. Uji organoleptik ada beda nyata untuk parameter visual dan rasa antara sup krim instan Caulerpa recemosa dengan kontrol, dimana kontrol lebih baik. Parameter tekstur, aroma dan penerimaan keselurahan tidak berbeda nyata.

\section{Saran}

1. Perlu pengujian lanjutan untuk memperbaiki sifat organoleptik terutama visual, tekstur, rasa, aroma, dan secara keseluruhan sup krim instan.

2. Perlu pengujian lanjutan untuk kadar logam berat, kadar serat produk, daya simpan produk, serta analisis ekonominya.

\section{UCAPAN TERIMA KASIH}

Penulis mengucapkan terima kasih pada lab CARC UKSW dan Bp Norson W. Totoda selaku laboran yang membantu penelitian ini dari awal hingga akhir. Kami juga mengucapkan kepada Bp Bonifacius Arbanto-SSI Indonesia yang membantu dalam penyediaan rumput laut.

\section{DAFTAR PUSTAKA}

AOAC. 2005. Official Methods of Analysis of AOAC International. In Association of Official Analysis Chemists International. 1058-59.

Asgar A, Zain S, Widyasanti A, Wulan AJ Hort. 2013. Kajian karakteristik proses pengeringan jamur tiram (Pleurotus sp.) menggunakan mesin pengering vakum. Jurnal Hortikultura. 23 (4): 379-389

BSN. 1999. SNI 01-4967-1999 Sup Krim Instan. Pusat Standarisasi Nasional Industri. Jakarta.

Farid MW, Ibrahim R, Dewi EN, Susanto E, Amalia U. 2013. Profil rumput laut Caulerpa racemosa dan Gracilaria verrucosa sebagai edible food. Jurnal Saintek Perikanan. 9 (1): 68-74.

Fellow PJ dan Ellis. 1992. Food Processing Technology Principles and Practice. London. Ellis Horwood.

Hambali E, Suryani A dan Wadli. 2004. Membuat Aneka Olahan Rumput Laut. Jakarta : Penebar Swadaya.

Hikmah. 2015. Strategi Pengembangan industri pengolahan komoditas rumput laut E.cotonii 
untuk peningkatan nilai tambah di sentra kawasan industrialisasi. Jurnal Kebijakan Sosek KP. 5 (1): 27-36.

Irwan WS. 2017. Pengembangan Produk krim sup instan tinggi betakaroten berbasis labu kuning (Cucurbita moschata) untuk lanjut usia (lansia). [Tesis]. Bogor. Institut Pertanian Bogor.

Lantah PL, Montolalu LADY, dan Reo AR. 2017. Kandungan fitokimia dan aktivitas antioksidan ekstrak metanol rumput laut Kappaphycus alvarezii. Jurnal Media Teknologi Hasil Perikanan. 5 (3): 167-173.

Lasabuda R. 2013. Pembangunan wilayah pesisir dan lautan dalam perspektif negara kepulauan Republik Indonesia. Jurnal Ilmiah Platax. 1 (2): 92-101.

Lípová L, Krchňák P, Komenda J, Ilík P. 2010. Heat-induced disassembly and degradation of chlorophyll-containing protein complexes in vivo. Biochimica et Biophysica Acta Bioenergetics. 1797 (1): 63-70. doi 10.1016/j.bbabio.2009.08.001.

Merdekawati W dan Susanto AB. 2009. Kandungan dan komposisi pigmen rumput laut serta potensinya untuk kesehatan. Squalen. 4 (2): 41-47.

Ornano L, Donno Y, Sanna C, Ballero M, Serafini M, Bianco A. 2014. Phytochemical study of Caulerpa racemosa (Forsk.) J. Agarth, an invading alga in the habitat of la Maddalena archipelago. Natural Product Research. 28 (20): 1795-1799.

Pattama R dan Anong C. 2006. Nutritional evaluation of tropical green seaweeds Caulerpa lentillifera and Ulva reticulate.
Kasetsart Journal - Natural Science. 40 (Suppl,): 75-83.

Sanchez IAV, Villafranca MCR, dan Lazaro N. 2018. Estimation of chlorophyll content in local Caulerpa seaweeds using acetone DMSO and methanol. Research Journal Chemical Sciences. 8 (10): 1-5.

Santosa, Andasuryani, dan Kurniawan D. 2016. Karakteristik Tepung Rumput Laut (Eucheuma cottonii). National Conference of Applied Sciences, Engineering, Business and Information Technology. Politeknik Negeri Padang, 15 - 16 Oktober 2016. 346-361

Sarojini Y, Neelima P, dan Sujat B. 2015. The seasonal variations in distribution of photosynthetic pigments in four edible species of Chlorophyceae and the effect of light, dissolved oxygen and nutrients on their distribution. Annals Biological Research. 6 (3): 36-40.

SNI 01-4967-1999. 1999. Sup Krim Instan. Pusat Standarisasi Nasional Industri. Jakarta.

Tarigan OJ, Lestari S, dan Widiastuti I. 2016. Pengaruh jenis asam dan lama marinasi terhadap karakteristik sensoris, mikrobiologis, dan kimia naniura ikan nila (Oreochormis niloticus). Fishtech-Jurnal Teknologi Hasil Perikanan. 8 (2): 11-122.

Winarno FG, Fardiaz S, dan Fardiaz D. 1980. Pengantar Teknologi Pangan. Jakarta: Gramedia Pustaka Utama.

Yudasmara GA. 2014. Budidaya anggur laut (Caulerpa racemosa) melalui media tanam rigid quadrant nets berbahan bambu. Jurnal Sains dan Teknologi. 3 (2): 468-473. 